\title{
Temporal Dynamics of Brown Rot in Different Apple Management Systems and Importance of Dropped Fruit for Disease Development
}

\author{
I. J. Holb and H. Scherm
}

First author: Centre of Agricultural Sciences, University of Debrecen, P.O. Box 36, H-4015 Debrecen, Hungary; and second author: University of Georgia, Department of Plant Pathology, Athens 30602. Accepted for publication 3 April 2007.

\section{ABSTRACT}

Holb, I. J., and Scherm, H. 2007. Temporal dynamics of brown rot in different apple management systems and importance of dropped fruit for disease development. Phytopathology 97:1104-1111.

\begin{abstract}
Epidemic development of brown rot, caused by Monilinia fructigena, was monitored in integrated and organic apple orchards at two locations in eastern Hungary between 2002 and 2005 on three cultivars with early, midseason, and late ripening periods. Disease incidence and severity measures were affected significantly $(P<0.05)$ by management system (organic versus integrated) and cultivar, but there was no significant management system-cultivar interaction. Epidemics started 2 to 4 weeks earlier in organic orchards and on the early cv. Prima compared with integrated orchards and the late cv. Mutsu. Disease intensity increased markedly in the final 3 to 5 weeks before harvest and was considerably lower in integrated than in organic orchards. Final brown rot incidence on fruit in the tree was correlated with incidence on dropped fruit on the
\end{abstract}

orchard floor $(r>0.75, P<0.05)$, whereby the lag period from the appearance of the first symptomatic fruit on the ground to the occurrence of the first symptomatic fruit in the tree ranged from 2 weeks to 2 months, depending on the cultivar. The inflection point of the disease progress curve was attained first by fruit on the ground, followed successively by fruit in the lower, middle, and upper thirds of the tree canopy. This may indicate that dropped fruit that became infected early provided a source of inoculum for subsequent epidemics by serving as a bridge between sporulation from overwintered fruit mummies in the spring and the first fruit with sporulating lesions in the tree in midsummer. Removal of dropped fruit from the orchard floor resulted in a significantly lower disease incidence on fruit in the tree on all cultivars; thus, drop-removal may be useful as a brown rot management practice in apple orchards.

Additional keywords: disease management, Halus domestica.
Monilinia fructigena is an important fungal pathogen causing pre- and postharvest fruit rot (brown rot) in pome fruit orchards $(9,34)$. In Central Europe, the fungus is considered primarily a fruit rot pathogen $(11,16)$. In well-managed conventional and integrated apple orchards, both incidence of and yield losses due to brown rot are usually $<10 \%(5,25,30,35)$. However, considerable preharvest yield losses of up to $46 \%$ have been reported from organic apple orchards in Hungary (16). This suggests different dynamics of brown rot development between orchard management systems, but comparative studies to analyze brown rot epidemics in apple orchards subjected to different management approaches are currently lacking.

Humid weather and temperatures between 15 and $20^{\circ} \mathrm{C}$ in the spring induce asexual sporulation of $M$. fructigena on the surface of overwintered mummified fruit (8). In most European countries, conidia from fruit mummies are present by late May (35). However, the first infected fruit in the tree do not occur before the end of July or the beginning of August $(15,30,35)$. The 2-month period between the end of May and the end of July is too long for survival of conidia produced on overwintered mummies (33); hence, other sources of inoculum are needed to provide epidemic continuity in early summer (35). In apple, fruit drop occurs as a result of natural and mechanical thinning in June or early July; conidia from overwintered mummies could infect these fruit on the ground, which then may serve as a bridge, providing inoculum for subsequent infection of fruit in the tree. If this hypothesis holds true, then brown rot epidemics should start earlier on the

Corresponding author: I. J. Holb; E-mail address: holb@agr.unideb.hu

doi:10.1094/PHYTO-97-9-1104

(c) 2007 The American Phytopathological Society dropped fruit than on those in the tree, and removal of dropped fruit from the orchard floor should delay or reduce disease progression in the tree. Furthermore, disease progression and the relative importance of dropped fruit for epidemic development are likely to be influenced by the level of disease in the orchard and by cultivar ripening time. However, no previous studies have been carried out to analyze brown rot development on the orchard floor and in the tree separately throughout the season in relation to orchard management system and cultivar.

The aims of this project were to (i) characterize the dynamics of brown rot on fruit on the orchard floor and in the tree in integrated and organic apple production systems on cultivars with different ripening periods, (ii) quantify the relationship between epidemic progress on dropped fruit on the ground and on fruit in different tree height layers within the canopy, and (iii) evaluate the effect of removal of dropped fruit on brown rot development in an effort to improve brown rot management options for integrated and organic apple orchards.

\section{MATERIALS AND METHODS}

Orchard sites. A 4-year study (2002 through 2005) was carried out in two commercial apple orchards in eastern Hungary. The first orchard, located in Nagykálló $\left(47^{\circ} 31^{\prime} 60^{\prime \prime} \mathrm{N}, 21^{\circ} 37^{\prime} 60^{\prime \prime} \mathrm{E}\right)$, was 9.3 ha in area and consisted of a mixed stand of apple cultivars planted in alternating three-row strips. Between-row and within-row distances were 4 and $1.5 \mathrm{~m}$, respectively, and trees were $\approx 2.5 \mathrm{~m}$ tall. The orchard was divided into two blocks corresponding to integrated and organic management systems, each consisting of 62 rows. The two blocks were separated by a $3-\mathrm{m}-$ tall windbreak of Italian alder (Alnus cordata) and a 5-m-wide road. 
The second orchard, located in Eperjeske $(89 \mathrm{~km}$ north of the Nagykálló site) was 14.2 ha in area and also consisted of a mixed stand of cultivars. Between-row and within-row distances were 5 and $2 \mathrm{~m}$, respectively, and trees were $\approx 3.1 \mathrm{~m}$ tall. The orchard was divided into two blocks corresponding to integrated (82 rows) and organic (54 rows) management systems, separated by a $10-\mathrm{m}-$ wide road. Cultivars were planted in alternating three-row and two-row strips in the integrated and organic blocks, respectively.

Trees in both orchards had been planted in 1996 on M26 rootstock and were pruned to spindle shape. Orchard soil type was brown forest soil with alternating layers of clay. Bare soil, $0.5 \mathrm{~m}$ wide, was maintained in the rows, and grass was grown in the row middles. Orchards were not irrigated. A winter pruning before bud break and two summer prunings at the beginning of June and August were carried out each year. Mechanical fruit thinning (after natural thinning) was performed in early June uniformly for all cultivars in both production systems, which resulted in a mean number of $\approx 20 \mathrm{fruit} / \mathrm{m}^{2}$ on the ground underneath the trees. Grass in the row middles was cut with an orchard flail mower four times each year (early June, early July, early August, and early September) in the integrated blocks and twice a year (early July and early September) in the organic blocks.

Experimental design and treatments. At each site, the experimental design was a split-split plot with the 4 years as blocks, the two management systems as main plots (replicated four times), fruit drop removal as subplot, and apple cultivars as subsubplots. The pest management program in the integrated main plots followed the Hungarian integrated fruit production (IFP) guidelines, whereas those in the organic main plots were according to the Hungarian organic production guidelines derived from the European IFP (12) and the International Federation of Organic Agriculture Movements (IFOAM) organic production guidelines (20). Both sets of guidelines had been applied since the orchards were planted in 1996. Fungicides, insecticides, and herbicides used in the two production systems are listed in Table 1; application schedules were similar to those reported in a previous article (18). In the organic blocks, stable manure and compost were applied every other year, whereas the integrated orchards relied on annual application of synthetic fertilizers for nutrient supply.

Within each main plot, two fruit-drop-removal treatments were applied. Dropped and thinned fruit underneath half of the trees in each main plot were removed once a week from 20 May until 10 October whereas, in the nonremoval treatment, they were left in place during the entire season. Each removal or nonremoval subplot was split further into sub-subplots corresponding to early-, mid-, and late-season cvs. Prima, Jonathan, and Mutsu, respectively. Each main plot, subplot, and sub-subplot consisted of a minimum of 1,000, 500, and 150 trees, respectively.

Disease assessment. Within each sub-subplot, five trees were selected randomly for disease assessment every 7 to 9 days from 20 May until harvest (early September, second decade of September, and mid-October for Prima, Jonathan, and Mutsu, respectively). For orchard floor assessment, all fruit present on the ground underneath the trees were assessed for disease incidence and severity. For the latter assessment, the largest and the shortest diameters of the sporulating area on each fruit were measured with a Vernier caliper, and the mean of these two measurements was used to calculate sporulating area based on the equation for the area of a disc. Disease severity was expressed as square centimeters of sporulating area per fruit.

For tree assessment, 50 fruit per cultivar typical of the given phenological stage were observed on the selected five trees and assessed similarly. In addition, on the last assessment date of each month, each tree was divided into three canopy height classes (corresponding to the lower third, middle third, and upper third), and disease incidence and severity were determined separately for each height class. Altogether, 384,000 fruit were assessed for brown rot across the 4 years.
Data analyses. Brown rot incidence and severity data from the four replicate main plots were averaged to obtain a single value for each assessment date and used to calculate areas under the disease progress curve (AUDPC). Final brown rot incidence, severity, and AUDPC values were analyzed by split-split-plot analysis of variance separately for the two locations and for the tree and orchard floor data sets (Statistical Analysis System v. 8.1; SAS Institute, Cary, NC). Prior to the analyses, disease incidence values were arcsine-square root transformed.

In order to investigate the hypothesis that inoculum from dropped fruit on the ground can lead to fruit infection in the tree, final brown rot incidence levels in the tree and on the orchard floor were plotted against each other, and linear regression functions were fitted separately for each management system and drop-removal treatment. A $t$ test was used to determine whether the regression slopes were significantly different between the two drop-removal treatments $(\alpha=0.05)$. Additionally, Pearson's correlation coefficients were calculated among final disease incidence data for early-season cv. Prima and late-season cv. Mutsu in the following combinations: incidence on the soil for Prima versus incidence in the tree for Prima, incidence on the soil for Prima versus incidence in the tree for Mutsu, and incidence on the soil for Mutsu versus incidence in the tree for Mutsu. This analysis was done only for nonremoval treatments separately for integrated and organic management systems using Genstat 5 (release 4.1; Lawes Agricultural Trust, IACR, Rothamsted, UK).

To quantify time delays in epidemic progress between fruit in the tree and those on the ground, the lag period (expressed in days and in AUDPC units) in disease onset between the two types of fruit was calculated. In addition, nonlinear growth functions were fitted to disease incidence data by a nonlinear mixed-effect modeling approach using $\mathrm{R}$ version 2.0.0 (1) with the 'nlme' statistical package (27). Based on the overall goodness-of-fit, visual examination of standardized residuals versus predicted values, and Akaike's Information Criterion (7), a three-parameter logistic function was deemed most appropriate for describing disease progress data. The function is given by $y=y_{f} /\left(1+e^{-\beta(t-M)}\right)$, where $y$ is the disease incidence (\%) at time $t$ (days after 20 May), $y_{f}$ the estimated final disease incidence or upper asymptote, $\beta$ the estimated relative rate of disease progress $\left(\right.$ days $\left.^{-1}\right)$, and $M$ the inflection point (i.e., the time when the absolute rate $\mathrm{d} y / \mathrm{d} t$ is at a maximum). Fishers's protected least significant difference

TABLE 1. Fungicide, insecticide, and herbicide active ingredients used in apple orchards in Eperjeske and Nagykálló, Hungary, from 2002 to $2005^{z}$

\begin{tabular}{|c|c|}
\hline Integrated & Organic \\
\hline \multicolumn{2}{|l|}{ Fungicides } \\
\hline Captan, $50 \%$ & Calcium polysulfides, $29 \%$ \\
\hline Copper hydroxide, $77 \%$ & Copper hydroxide, $77 \%$ \\
\hline Copper sulfate, $350 \mathrm{~g} \mathrm{liter}^{-1}$ & Copper sulfate, $350 \mathrm{~g} \mathrm{liter}^{-1}$ \\
\hline Difenoconazole, $250 \mathrm{~g} \mathrm{liter}^{-1}$ & Elemental sulfur, $80 \%$ \\
\hline Dithianon, $70 \%$ & Elemental sulfur, $900 \mathrm{~g} \mathrm{liter}^{-1}$ \\
\hline \multicolumn{2}{|l|}{ Dodine, $500 \mathrm{~g} \mathrm{liter}^{-1}$} \\
\hline \multicolumn{2}{|l|}{ Kresoxim-methyl, $50 \%$} \\
\hline \multicolumn{2}{|l|}{ Pyrimethanil, $300 \mathrm{~g}$ liter $^{-1}$} \\
\hline \multicolumn{2}{|l|}{ Trifloxistrobin, $50 \%$} \\
\hline \multicolumn{2}{|l|}{ Insecticides } \\
\hline Acetampirid, $20 \%$ & Bacillus thuringiensis, $3.2 \%$ \\
\hline Fenoxicarb, $25 \%$ & Mineral oil, $90 \%$ \\
\hline Flufenzin, $200 \mathrm{~g} \mathrm{liter}^{-1}$ & Plant oil extract, $50 \%$ \\
\hline \multicolumn{2}{|l|}{ Hexytiazox, $10 \%$} \\
\hline \multicolumn{2}{|l|}{ Lufenuron, $50 \mathrm{~g}$ liter $^{-1}$} \\
\hline \multicolumn{2}{|l|}{ Mineral oil, $90 \%$} \\
\hline \multicolumn{2}{|l|}{ Teflubenzuron, $150 \mathrm{~g} \mathrm{liter}^{-1}$} \\
\hline \multicolumn{2}{|l|}{ Tiacloprid, $480 \mathrm{~g} \mathrm{liter}^{-1}$} \\
\hline \multicolumn{2}{|l|}{ Triflumuron, $25 \%$} \\
\hline \multicolumn{2}{|l|}{ Herbicides } \\
\hline Glyphosinate-ammonium, $360 \mathrm{~g} \mathrm{liter}^{-1}$ & \\
\hline
\end{tabular}

z Application schedules similar to those described by Holb et al. (17). 
tests $(\alpha=0.05)$ were applied to compare $M$ values estimated for disease progress curves for dropped fruit on the ground and those in the lower, middle, and upper canopy height layers in the tree.

\section{RESULTS}

Disease incidence. Analyses of variance of final brown rot incidence indicated significant $(P<0.05)$ differences among management systems, fruit-drop-removal treatments, and cultivars for disease development on the orchard floor and in the tree at both locations (Table 2). Results were very similar when disease severity and AUDPC values of incidence and severity were analyzed (data not shown). There were no significant two- or three-way interactions among treatment factors; hence, main effects of the three factors were examined in more detail (Fig. 1). Final brown rot incidence (both on the orchard floor and in the tree) was two to four times higher in the organic than in the integrated management system. Removal of dropped fruit greatly (10 to 20 times) reduced the incidence of symptomatic fruit on the orchard floor and also resulted in a reduction of final brown rot incidence in the tree. In addition, final brown rot incidence increased in the order of early-, mid-, and late-season cultivars.

Disease progress. Data collected in the Nagykálló orchard in 2004 are used to illustrate patterns of disease progress typical of the eight site-year combinations (Figs. 2 and 3). In the nonremoval treatment, disease progress on dropped fruit on the ground was slower in the integrated than in the organic management system (Fig. 2). Disease onset on dropped fruit for the earlyseason cv. Prima occurred at the end of May in the organic plots and 2 to 3 weeks later in the integrated plots. At the beginning of June, $\approx 3$ weeks after mechanical thinning, disease incidence in the organic plots increased sharply. At the same time, disease incidence on the ground in integrated plots was zero or near zero. Disease progress on the mid- and late-season cvs. Jonathan and Mutsu followed that on Prima with 1 to 2 and 3 to 4 weeks delay, respectively. In the drop-removal treatment, brown rot incidence on the orchard floor was generally low $(<3 \%)$ throughout the season, regardless of management system or cultivar.
Disease progress in the tree was slower in the integrated than in the organic management system and in the plots subjected to the drop-removal treatment compared with those in which fruit drops were not removed (Fig. 3). Disease onset on the early-season cv. Prima occurred at the beginning of June in the organic plots and 2 to 3 weeks later in the integrated plots. Drop removal delayed disease onset in the tree for an additional 2 to 3 weeks. In all cases, mid- and late-season cvs. Jonathan and Mutsu followed disease onset on Prima with 1 to 2 and 3 to 4 weeks delay, respectively. Disease in the tree progressed slowly after the first appearance of symptoms but increased markedly in the final 3 to 5 weeks before harvest. Late-season cv. Mutsu showed the most rapid disease increase and the highest final disease incidence in all treatments.

Relationships between brown rot development on the orchard floor and in the tree. Final disease incidence data for fruit in the tree were plotted against those from the orchard floor separately for fruit-drop-removal treatments and management systems (Fig. 4). In the drop-removal plots, final disease incidence on the orchard floor showed no significant relationship with that in the tree $(P=0.1079$ and 0.1534 for integrated and organic plots, respectively). However, when dropped fruit were not removed, the relationship was highly significant $(r=0.760, P=$ 0.002 and $r=0.936, P<0.001$ for the integrated and organic plots, respectively), with the slopes being significantly different between the two management systems ( $P=0.019$ according to a $t$ test). When associations between final disease incidence in the tree and on the orchard floor were investigated further, the highest correlation coefficients were observed between tree incidence on late-season cv. Mutsu and orchard floor incidence on early-season cv. Prima (Table 3). Correlations were lower in organic plots than in integrated plots.

The average lag period between the time of disease onset on the orchard floor versus the tree was 14.9 to 51.1 and 24.6 to 62.7 days for the integrated and organic management systems, respectively (Table 4). Variation in the lag period among cultivars, summarized by the coefficient of variation, was higher when lag period was expressed in AUDPC units instead of time. As expected, the longest lag period was observed between orchard floor

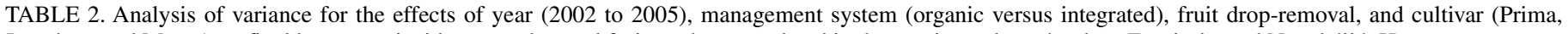
Jonathan, and Mutsu) on final brown rot incidence on dropped fruit on the ground and in the tree in apple orchards at Eperjeske and Nagykálló, Hungary ${ }^{z}$

\begin{tabular}{|c|c|c|c|c|c|c|c|}
\hline \multirow[b]{2}{*}{ Site and source of variation } & \multirow[b]{2}{*}{ df } & \multicolumn{3}{|c|}{ Fruit on the orchard floor } & \multicolumn{3}{|c|}{ Fruit in the tree } \\
\hline & & MS & $F$ & $P$ & MS & $F$ & $P$ \\
\hline \multicolumn{8}{|l|}{ Eperjeske } \\
\hline Year $(Y)$ & 3 & 73.39 & 1.62 & 0.3501 & 25.07 & 5.37 & 0.1004 \\
\hline Management (M) & 1 & 710.71 & 15.72 & 0.0287 & $2,026.70$ & 434.48 & 0.0002 \\
\hline Main plot error & 3 & 45.19 & 4.66 & & & & \\
\hline Drop removal $(\mathrm{R})$ & 1 & $5,386.92$ & 41.50 & 0.0007 & 120.65 & 83.93 & $<0.0001$ \\
\hline $\mathrm{M} \times \mathrm{R}$ & 1 & 327.08 & 2.52 & 0.1635 & 3.91 & 2.72 & 0.1502 \\
\hline Subplot error & 6 & 129.80 & 1.44 & & & & \\
\hline Cultivar (C) & 2 & 28.52 & 3.57 & 0.0440 & 29.91 & 8.99 & 0.0012 \\
\hline $\mathrm{M} \times \mathrm{C}$ & 2 & 5.32 & 0.67 & 0.5232 & 2.09 & 0.63 & 0.5422 \\
\hline $\mathrm{R} \times \mathrm{C}$ & 2 & 15.57 & 1.95 & 0.1644 & 0.35 & 0.11 & 0.9002 \\
\hline $\mathrm{M} \times \mathrm{R} \times \mathrm{C}$ & 2 & 4.64 & 0.58 & 0.5672 & 2.41 & 0.73 & 0.4943 \\
\hline Sub-subplot error & 24 & 7.99 & $\ldots$ & $\ldots$ & 3.32 & $\ldots$ & $\ldots$ \\
\hline \multicolumn{8}{|l|}{ Nagykálló } \\
\hline Year (Y) & 3 & 55.83 & 0.78 & 0.5797 & 23.30 & 4.16 & 0.1360 \\
\hline Management (M) & 1 & 760.02 & 10.58 & 0.0474 & $2,195.11$ & 391.93 & 0.0003 \\
\hline Main plot error & 3 & 71.86 & 5.60 & & & & \\
\hline Drop removal (R) & 1 & $6,242.64$ & 59.56 & 0.0002 & 227.94 & 407.24 & $<0.0001$ \\
\hline $\mathrm{M} \times \mathrm{R}$ & 1 & 340.27 & 3.25 & 0.1216 & 0.01 & 0.01 & 0.9116 \\
\hline Subplot error & 6 & 104.80 & 0.56 & & & & \\
\hline Cultivar (C) & 2 & 20.82 & 3.81 & 0.0365 & 25.63 & 9.99 & 0.0007 \\
\hline $\mathrm{M} \times \mathrm{C}$ & 2 & 3.90 & 0.71 & 0.4996 & 3.05 & 1.19 & 0.3212 \\
\hline $\mathrm{R} \times \mathrm{C}$ & 2 & 13.72 & 2.51 & 0.1021 & 0.81 & 0.81 & 0.4587 \\
\hline $\mathrm{M} \times \mathrm{R} \times \mathrm{C}$ & 2 & 2.32 & 0.43 & 0.6582 & 0.13 & 0.13 & 0.8772 \\
\hline Sub-subplot error & 24 & 5.46 & $\ldots$ & $\ldots$ & 2.56 & $\ldots$ & $\ldots$ \\
\hline
\end{tabular}

z Based on arcsine-square root-transformed disease incidence data. 
incidence of early-season cv. Prima and tree incidence of lateseason cv. Mutsu in both management systems.

At the end of the lag period, sporulating area on fruit on the ground (an indicator of inoculum availability for fruit infection in the tree) was considerably larger in the organic plots than in the integrated plots and underneath trees of early-maturing cv. Prima compared with the later-maturing cvs. Jonathan and Mutsu (Table 5). For example, at the time of disease onset in trees of Prima in
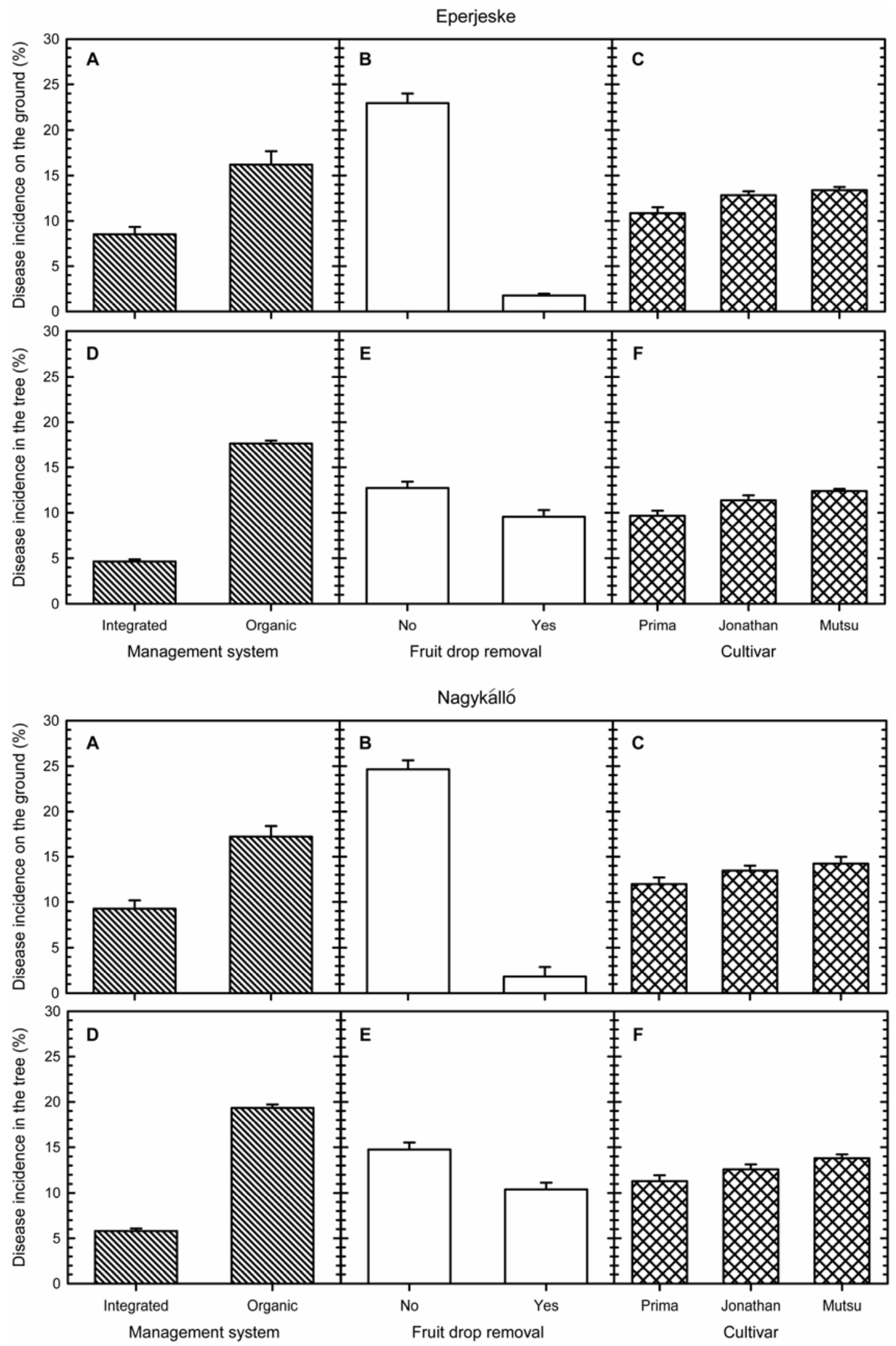

Fig. 1. Main effects of $\mathbf{A}$ and $\mathbf{D}$, management system; $\mathbf{B}$ and $\mathbf{E}$, fruit drop-removal; and $\mathbf{C}$ and $\mathbf{F}$, cultivar on final brown rot incidence on $\mathbf{A}$ to $\mathbf{C}$, dropped fruit on the ground and $\mathbf{D}$ to $\mathbf{F}$, fruit in the tree in apple orchards at Eperjeske and Nagykállo, Hungary, from 2002 to 2005 . Values are means and standard errors of 48 data points for each management system and fruit drop-removal treatment and 32 data points for each cultivar. 
the integrated plots, no sporulation by $M$. fructigena was noted on dropped fruit of Jonathan and Mutsu; in contrast, sporulating lesions were present on dropped fruit of all three cultivars at the time of disease onset in trees of Prima in the organic plots. At the time of disease onset in trees of Mutsu, all three cultivars could have served as ground inoculum sources in both the integrated and organic plots (Table 5).

Disease development in different tree canopy heights. The times when the curves describing disease progress on dropped fruit on the ground and in different tree heights reached their inflection points (i.e., the times when rates of disease progress peaked) ranged from 85.6 to 146.1 and 80.1 to 139.3 days after 20 May in the integrated and organic plots, respectively (Table 6). In general, inflection points were attained first on dropped fruit, followed by fruit in lower, middle, and upper tree canopy layers. Differences in these times were most pronounced in the mid- and late-ripening cultivars in the organic production system.

\section{DISCUSSION}

This study showed that management system and cultivar harvest season played an important role in epidemic development of brown rot caused by $M$. fructigena in Hungarian apple orchards. In addition, it documented and quantified an epidemiological bridge effect, whereby infected fruit drops on the ground served as an inoculum source for subsequent brown rot development in the tree. The close correlation between final disease incidence levels in the tree and on the ground and the fact that fruit drop removal from the orchard floor reduced disease in the tree provided support for an important epidemiological role of this bridge effect.
Dropped fruit on the orchard floor showed symptoms and signs of infection by $M$. fructigena several weeks before symptoms were visible on fruit in the tree, and disease incidence and severity were consistently higher on dropped fruit. Previous studies assessed fruit brown rot only in the tree $(30,35)$, with one exception in organic apple orchards (15). In the latter study, it also was noted that final fruit rot incidence was significantly higher on the orchard floor. In apple, early fruit drops result primarily from natural or mechanical thinning, whereas later drops (closer to harvest) are mainly a consequence of injury by insects. Regardless of the cause of fruit drop, affected fruit generally become injured when impacting onto the ground, where they undergo an accelerated senescence process $(10,14)$, leading to increased susceptibility to infection by $M$. fructigena. On the orchard floor, soil surface moisture provides more favorable conditions for fungal development, which may result in faster brown rot development coupled with profuse sporulation of the fungus on dropped fruit.

There was an increase of disease on dropped fruit in the organic plots during the 3-week period after mechanical thinning for all cultivars, years, and locations. This period apparently provided sufficient time for the thinned fruit to become infected and for $M$. fructigena to sporulate on the senescent or injured fruit on the ground. A similar increase was not observed in the integrated plots, where similar numbers of fruit had been thinned from the trees. Due to less frequent mowing, the grass in the alleys was taller in the organic plots, which may have protected dropped fruit from fungicide exposure and provided a more humid environment for fruit infection and fungal sporulation than the short grass covering the alleys in the integrated blocks. Row middles in

\section{Integrated}

Organic

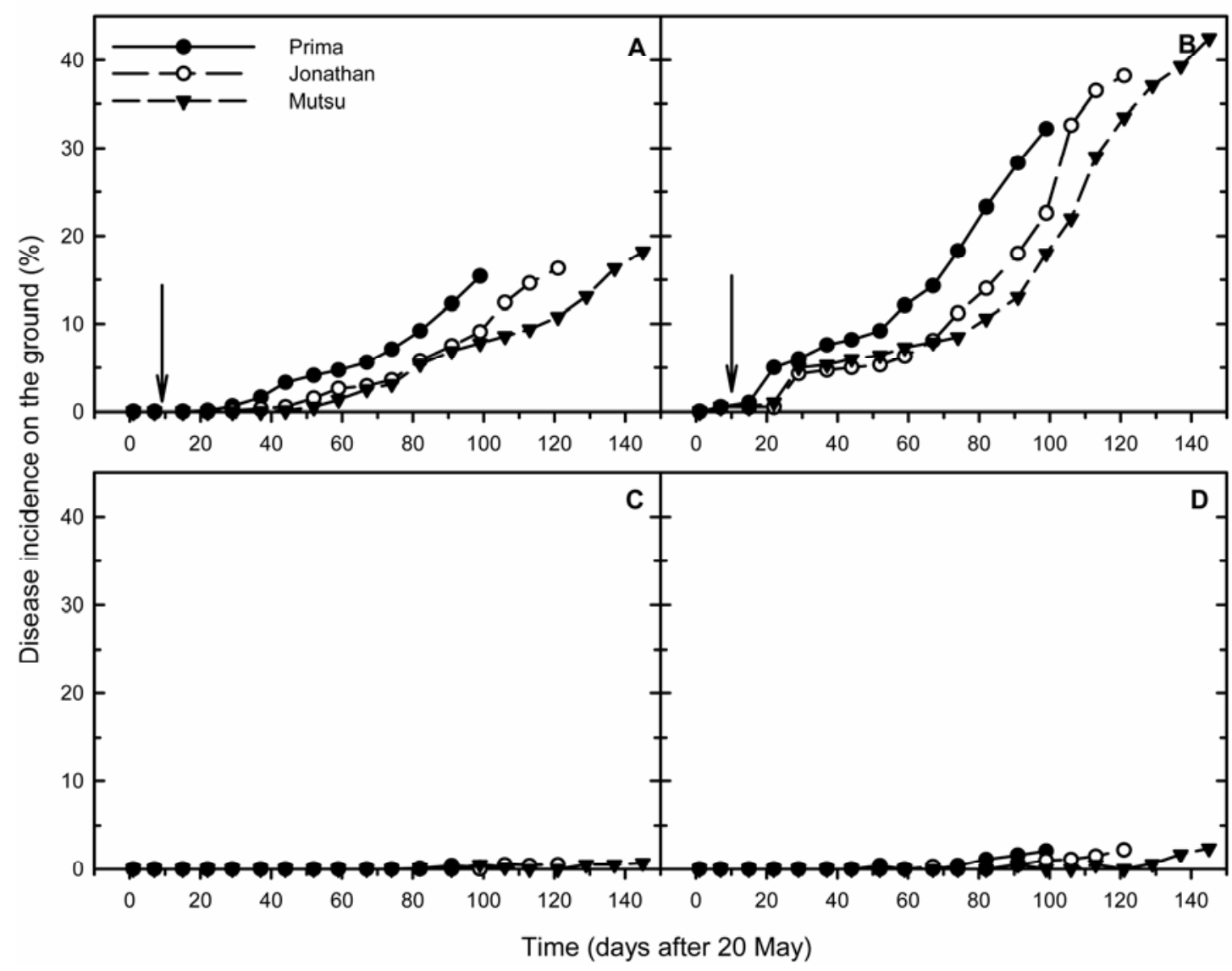

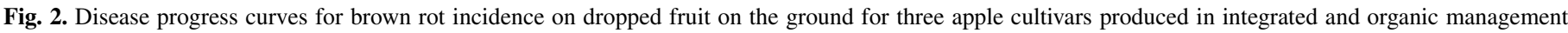

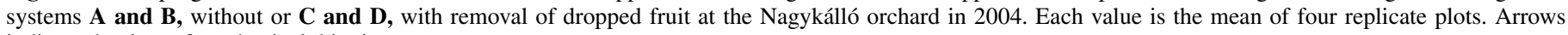
indicate the time of mechanical thinning. 
organic apple orchards generally are mowed less frequently because tall grass provides a favorable habitat for several natural enemies of apple pests $(31,32)$.

In the case of American brown rot caused by $M$. fructicola, thinned fruit on the ground are well known as an important inoculum source for fruit rot in stone fruit orchards in humid $(6,23)$ and semiarid (19) climates of the United States and Canada. However, M. fructicola also causes blossom blight in the spring, which provides inoculum for infection of green fruit in the tree $(13,21,26,28)$. In contrast, $M$. fructigena does not cause blossom blight in apple orchards in Central Europe $(11,16)$; hence, in this pathosystem, infected fruit drops on the ground likely are more important as an inoculum source to bridge the time from the end of sporulation on mummified fruit in early spring and the first sporulation on infected fruit in the tree in the summer.

Brown rot progress curves attained their inflection points first on fruit on the orchard floor, followed by fruit in lower canopy

\section{Integrated}

\section{Organic}

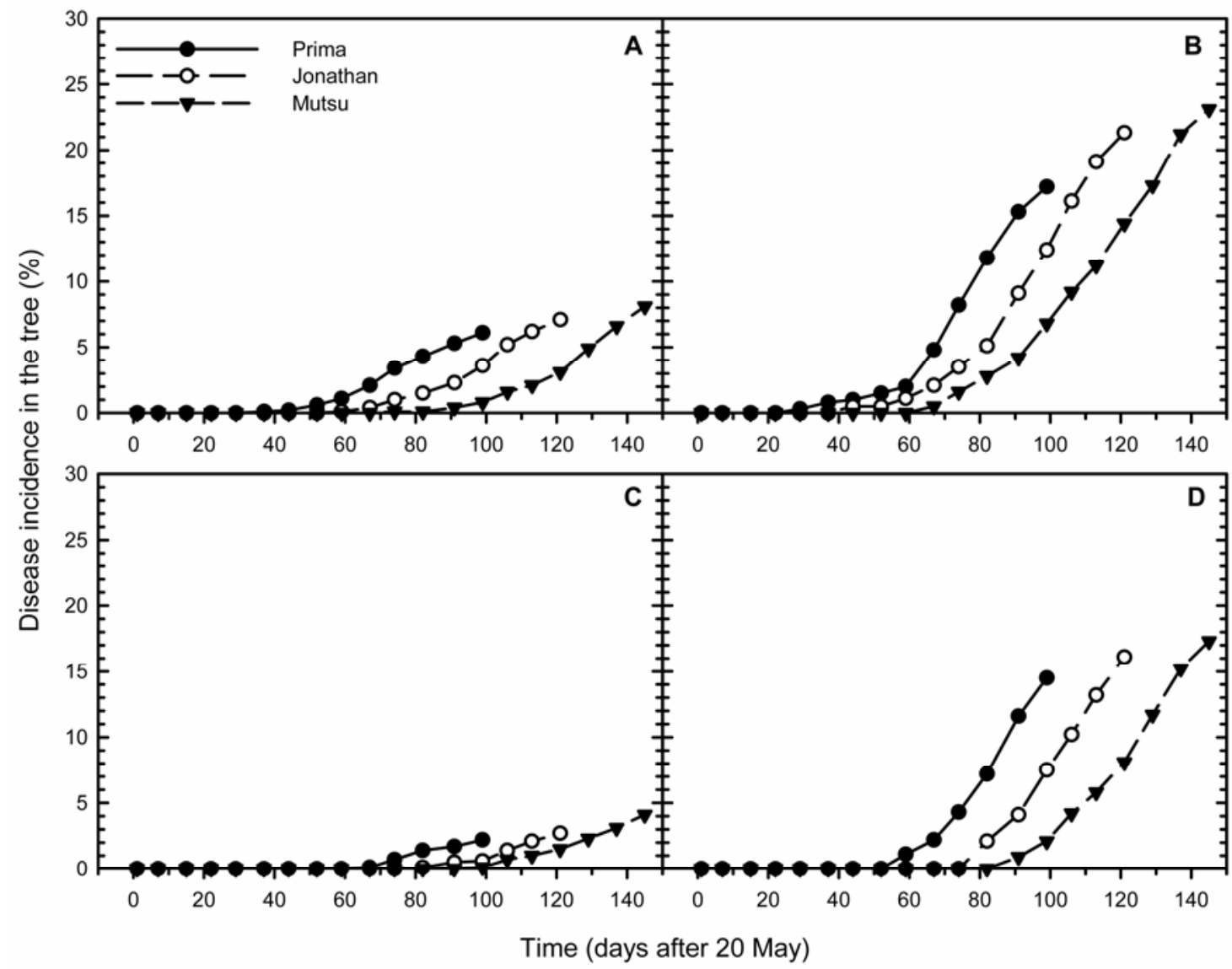

Fig. 3. Disease progress curves for brown rot incidence on fruit in the tree for three apple cultivars produced in integrated and organic management systems A and $\mathbf{B}$, without or $\mathbf{C}$ and D, with removal of dropped fruit at the Nagykálló orchard in 2004. Each value is the mean of four replicate plots.

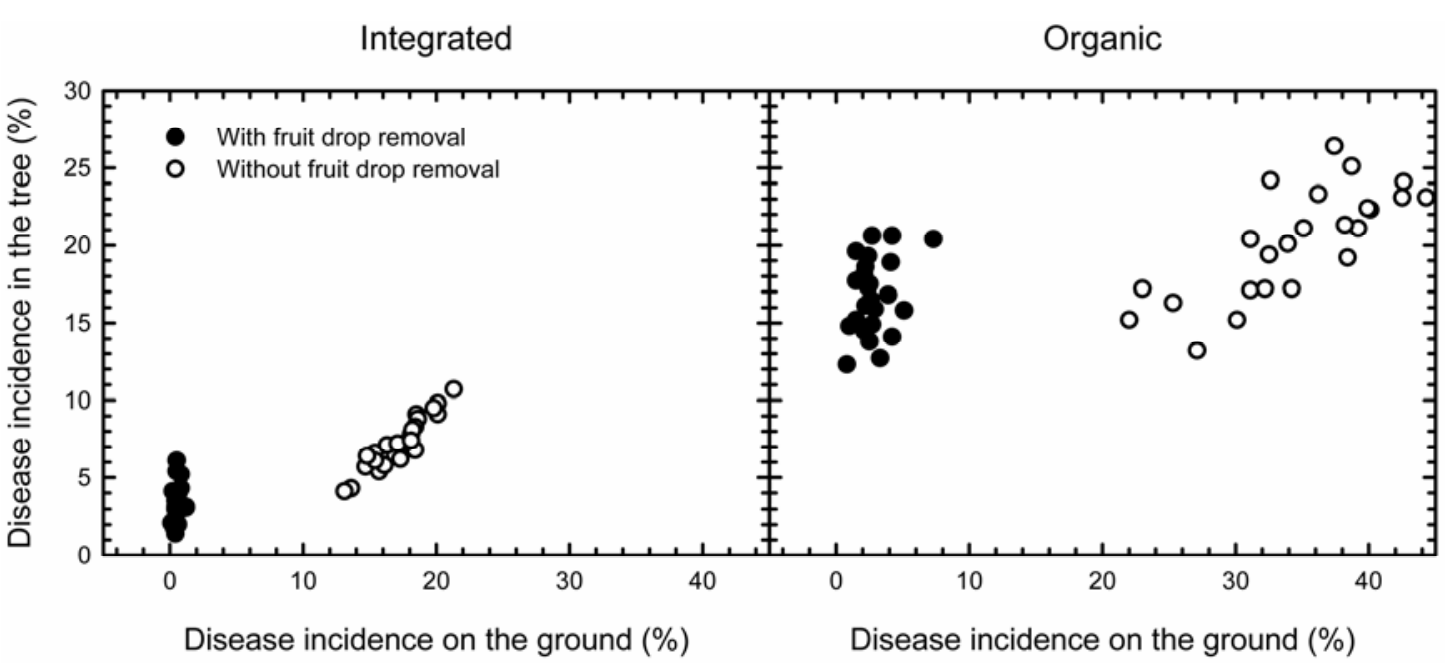

Fig. 4. Relationships between final brown rot incidence on fruit in the tree and on dropped fruit on the ground in organic and integrated plots in apple orchards at Eperjeske and Nagykálló, Hungary, from 2002 to 2005. Dropped fruit were either removed (•) or not removed (O) from the orchard floor at weekly intervals. 
TABLE 3. Pearson's correlation coefficients and associated significance levels (in parentheses) between final brown rot incidence on fruit in the tree and on dropped fruit on the ground in apple orchards at Eperjeske and Nagykálló, Hungary, from 2002 to $2005^{x}$

\begin{tabular}{|c|c|c|c|c|}
\hline \multirow{2}{*}{\multicolumn{2}{|c|}{ System, cultivar in tree }} & \multicolumn{3}{|c|}{$\begin{array}{l}\text { Cultivar for disease incidence on } \\
\text { dropped fruit on the ground }{ }^{z}\end{array}$} \\
\hline & & & Prima & Mutsu \\
\hline \multicolumn{5}{|l|}{ Integrated } \\
\hline \multicolumn{2}{|l|}{ Prima } & \multicolumn{2}{|c|}{0.907 (0.0009) } & $0.792(0.0084)$ \\
\hline Mutsu & & \multicolumn{2}{|c|}{$0.958(0.0001)$} & $0.892(0.0014)$ \\
\hline \multicolumn{5}{|l|}{ Organic } \\
\hline Prima & & \multicolumn{2}{|c|}{$0.762(0.0141)$} & $0.684(0.0289)$ \\
\hline Mutsu & & \multicolumn{2}{|c|}{$0.853(0.0035)$} & $0.798(0.0088)$ \\
\hline \multicolumn{5}{|c|}{$\begin{array}{l}\text { x Only treatments in which dropped fruit were not removed from the o } \\
\text { floor were considered in the analysis for each cultivar combination ( } n \\
{ }^{y} \text { Management system and cultivar for disease incidence in the tree. } \\
\text { z Prima and Mutsu are early- and late-maturing cultivars, respectively. }\end{array}$} \\
\hline \multicolumn{5}{|c|}{$\begin{array}{l}\text { TABLE 4. Lag periods between brown rot onset on fruit in the tree versus on } \\
\text { dropped fruit on the ground in apple orchards at Eperjeske and Nagykállo, } \\
\text { Hungary, from } 2002 \text { to } 2005^{\mathrm{v}}\end{array}$} \\
\hline \multirow[b]{2}{*}{ System $^{w}$} & \multicolumn{2}{|c|}{ Comparison $^{\mathrm{x}}$} & \multicolumn{2}{|c|}{ Lag period ${ }^{\mathrm{y}}$} \\
\hline & Ground & Tree & Days & AUDPC (percent-days) ${ }^{\mathrm{z}}$ \\
\hline \multirow[t]{3}{*}{ Integrated } & Prima & Prima & $14.9 \pm 39.2$ & $13.4 \pm 74.3$ \\
\hline & Prima & Mutsu & $51.1 \pm 10.3$ & $168.0 \pm 18.8$ \\
\hline & Mutsu & Mutsu & $30.7 \pm 14.6$ & $49.4 \pm 26.3$ \\
\hline \multirow[t]{3}{*}{ Organic } & Prima & Prima & $24.6 \pm 38.7$ & $62.9 \pm 34.3$ \\
\hline & Prima & Mutsu & $62.7 \pm 14.7$ & $393.2 \pm 35.8$ \\
\hline & Mutsu & Mutsu & $54.0 \pm 16.1$ & $233.1 \pm 68.9$ \\
\hline
\end{tabular}

${ }^{\mathrm{v}}$ Only treatments in which dropped fruit were not removed were considered in the analysis for each cultivar combination $(n=8)$.

w Orchard management system.

${ }^{x}$ Cultivar and disease onset on dropped fruit (Ground) and in the tree (Tree).

Prima and Mutsu are early- and late-maturing cultivars, respectively.

y Mean \pm coefficient of variation.

${ }^{\mathrm{z}}$ Area under disease progress curve (AUDPC) based on disease incidence. layers of the tree. Thus, disease progress in higher tree canopy layers lagged behind that of lower canopy layers, suggesting a stepwise vertical spread of the disease from inoculum sources on the ground to successively higher layers in the tree canopy. Vertical spread of pathogen spores and subsequent disease gradients from the orchard floor to the tree were demonstrated for other fruit diseases, such as apple scab caused by Venturia inaequalis $(2,3)$. In our study, differences in the times to reaching the inflection point were most evident for the organic plots and on the midand late-season cultivars. In integrated plots, especially on the early-season cultivar, disease levels may have been too low to document such an effect.

In the tree, disease onset occurred significantly earlier on the early-season cultivar compared with the later ones, most likely because fruit on the former cultivar begin to mature earlier and mature fruit are more susceptible infection by to $M$. fructigena $(29,30,35)$. However, final disease incidence was higher on the late-season cultivar, likely due to inoculum build-up toward the end of the season from infected fruit (both on the ground and in the tree) on earlier-maturing cultivars. Moreover, insect damage was more severe on the later-maturing cultivars by the end of the growing season (I. J. Holb, unpublished), probably due to the longer time of exposure to insect damage.

The lower brown rot incidence in integrated compared with organic plots likely was due to the use of highly effective systemic fungicides in the former plots, whereas only less-effective copper and sulfur fungicides are approved in organic apple production $(17,18,20)$. Moreover, because fruit injury plays an important role in the epidemiology of brown rot caused by $M$. fructigena $(4,9,22,30,35)$, more effective insect management may have reduced the availability of wound infection sites in integrated plots compared with organic plots. Additionally, insect-damaged apple fruit mature 5 to 20 days earlier than unaffected fruit (25), which may expand the favorable period for infection by M. fructigena.

TABLE 5. Brown rot severity (square centimeters of sporulating area per fruit) on dropped fruit on the ground at the time of appearance of the first symptoms on fruit in the tree in apple orchards at Eperjeske and Nagykálló, Hungary, from 2002 to $2005^{y}$

\begin{tabular}{|c|c|c|c|c|c|c|}
\hline \multirow[b]{3}{*}{ Cultivar for dropped fruit ${ }^{z}$} & \multicolumn{6}{|c|}{ Cultivar for disease onset in the tree } \\
\hline & \multicolumn{3}{|c|}{ Integrated } & \multicolumn{3}{|c|}{ Organic } \\
\hline & Prima & Jonathan & Mutsu & Prima & Jonathan & Mutsu \\
\hline Mutsu & 0.00 & 0.00 & 0.05 & 0.10 & 0.15 & 0.42 \\
\hline
\end{tabular}

y Only treatments in which dropped fruit were not removed were considered in the analysis for each cultivar combination $(n=8)$. Prima, Jonathan, and Mutsu are early-, mid-, and late-maturing cultivars, respectively.

${ }^{\mathrm{z}}$ Cultivar for disease severity on dropped fruit on the ground.

TABLE 6. Times (expressed in days after 20 May) when disease progress curves of brown rot incidence on dropped fruit on the ground and in different canopy layers in the tree reached their inflection points in apple orchards at Eperjeske and Nagykálló, Hungary, from 2002 to $2005^{\mathrm{y}}$

\begin{tabular}{|c|c|c|c|c|c|c|}
\hline \multirow[b]{3}{*}{ Management system, tree level } & \multicolumn{6}{|c|}{ Site and cultivar ${ }^{\mathrm{Z}}$} \\
\hline & \multicolumn{3}{|c|}{ Eperjeske } & \multicolumn{3}{|c|}{ Nagykálló } \\
\hline & Prima & Jonathan & Mutsu & Prima & Jonathan & Mutsu \\
\hline Orchard floor & $88.1 \mathrm{a}$ & $111.8 \mathrm{a}$ & $139.1 \mathrm{a}$ & $86.2 \mathrm{a}$ & $113.5 \mathrm{a}$ & $137.3 \mathrm{a}$ \\
\hline Lower canopy & $89.7 \mathrm{a}$ & $113.8 \mathrm{a}$ & $137.4 \mathrm{a}$ & $87.2 \mathrm{a}$ & $114.5 \mathrm{a}$ & $137.2 \mathrm{a}$ \\
\hline Middle canopy & $85.6 \mathrm{a}$ & $113.1 \mathrm{a}$ & $140.4 \mathrm{a}$ & $88.1 \mathrm{a}$ & $111.3 \mathrm{a}$ & $143.4 \mathrm{~b}$ \\
\hline Upper canopy & $86.1 \mathrm{a}$ & $115.2 \mathrm{a}$ & $146.1 \mathrm{~b}$ & $80.5 \mathrm{~b}$ & $119.6 \mathrm{~b}$ & $145.1 \mathrm{~b}$ \\
\hline Lower canopy & $82.4 \mathrm{a}$ & $106.1 \mathrm{a}$ & $126.7 \mathrm{~b}$ & $82.9 \mathrm{a}$ & $112.3 \mathrm{~b}$ & $127.1 \mathrm{~b}$ \\
\hline Middle canopy & $85.7 \mathrm{~b}$ & $109.4 \mathrm{~b}$ & $133.8 \mathrm{c}$ & $87.9 \mathrm{~b}$ & $118.4 \mathrm{c}$ & $132.4 \mathrm{c}$ \\
\hline Upper canopy & $87.2 \mathrm{~b}$ & $115.3 \mathrm{c}$ & $139.3 \mathrm{~d}$ & $88.5 \mathrm{~b}$ & $120.5 \mathrm{c}$ & $138.7 \mathrm{~d}$ \\
\hline
\end{tabular}

${ }^{y}$ Values correspond to the inflection point, $M$, of a three-parameter logistic function describing the disease progress curves. Means within the same column followed by the same letter are not significantly different based on Fisher's protected least significant difference test $(n=4)$.

z Prima, Jonathan, and Mutsu are early-, mid-, and late-maturing cultivars, respectively. 
The findings of this study are relevant to the development of improved brown rot management options in integrated and organic apple orchards. First, because disease onset on the orchard floor precedes that in the tree by several weeks, dropped fruit on the ground could be scouted to provide an early warning for anticipating infection or disease onset on fruit in the tree. This approach may be complicated by the large variation in lag periods across sites and years, especially for the early-season cv. Prima, as observed here. In addition, infected fruit on the ground may be obscured by the infrequently mowed grass present in many organic apple orchards.

Second, regular removal of infected dropped fruit from the orchard floor can delay disease development and reduce final brown rot incidence. However, manual removal of thinned fruit is very time consuming and costly (19) and, therefore, probably will not be practical for integrated orchards. In organic orchards, on the other hand, where there are no effective chemical control options and where higher labor costs may be acceptable due to higher product prices, manual removal of thinned fruit may be economically feasible. It also may be possible to develop systems whereby fruit are thinned directly into picking baskets or other containers, thereby avoiding the extra step of gathering thinned fruit from the ground. Either way, fruit drop removal would have additional benefits in organic orchards (e.g., removal of breeding sites for insect pests such as the codling moth, Cydia pomonella [24], and the use of the collected fruit for composting). The compost then can be used as natural fertilizer for the orchard.

As an alternative to manual removal of dropped fruit, other cultural practices such as disking or rototilling could be applied, or fruit on the orchard floor could be treated with fungicides, herbicides, or biological agents to expedite their decomposition or to suppress sporulation by $M$. fructigena. Various means of inoculum reduction in integrated and organic pome fruit orchards are currently under investigation by the writers, as is an assessment of the role of fruit injuries by various wounding agents in the two management systems.

\section{ACKNOWLEDGMENTS}

The study was supported in part by the Hungarian Scientific Research Fund (OTKA F043503) and a János Bolyai Research Fellowship awarded to I. J. Holb. We thank L. Halász and J. Katona for their excellent cooperation in this research.

\section{LITERATURE CITED}

1. Anonymous. 2004. R: A Language and Environment for Statistical Computing. R Foundation for Statistical Computing, Vienna.

2. Aylor, D. E. 1995. Vertical variation of aerial concentration of Venturia inaequalis ascospores in an apple orchard. Phytopathology 85:175-181.

3. Aylor, D. E. 1998. The aerobiology of apple scab. Plant Dis. 82:838-849.

4. Batra, L. R. 1991. World Species of Monilinia (Fungi): Their Ecology, Biosystematics and Control. Mycologia Memoir No. 16. J. Cramer, Berlin.

5. Berrie, A. M. 1989. Storage rots of apple and pear in South East England 1980-88: Incidence and fungicide resistance. Pages 229-239 in: Integrated Control of Pome Fruit Diseases. C. Gessler, D. J. Butt, and B. Koller, eds. IOBC, Brissago, Switzerland.

6. Biggs, A. R., and Northover, J. 1985. Inoculum sources for Monilinia fructicola in Ontario peach orchards. Can. J. Plant Pathol. 7:302-307.

7. Burnham, K. P. and Anderson, D. 2002. Model Selection and Multimodel Interference, 2nd ed. Springer, New York.

8. Byrde, R. J. W. 1954. Observation on the sporulation of Sclerotinia fructigena on mummified apples and plums in late spring and summer. Pages 163-166 in: Report of Agricultural and Horticultural Research Station, University of Bristol, UK.

9. Byrde, R. J. W., and Willetts, H. J. 1977. The Brown Rot Fungi of Fruit. Their Biology and Control. Pergamon, Oxford.

10. Childers, N. F., Morris, J. R., and Sibbett G. S. 1995. Modern Fruit Science: Orchard and Small Fruit Culture. Horticultural Publications,
Gainesville, FL.

11. Cimanowski, J., and Pietrzak, B. 1991. Preliminary observations on the occurrence and control of brown rot (Monilinia fructigena (Aderh. \& Ruhl.) Honey) on apples. Pr. Inst. Sadow. Kwiaciarstwa Skierniewicach Ser. A 30:79-87.

12. Cross, J. V., and Dickler, E. 1994. Guidelines for integrated production of pome fruits in Europe. Technical guideline III. IOBC/WPRS Bull. 17(9): $1-8$

13. Emery, K. M., Michailides, T. J., and Scherm, H. 2000. Incidence of latent infection of immature peach fruit by Monilinia fructicola and relationship to brown rot in Georgia. Plant Dis. 84:853-857.

14. Fukui, H., Imakawa, S., and Tamura, T. 1984. Relationship between early drop of apple fruit, ethylene evolution and formation of abscission layer. J. Jpn. Soc. Hortic. Sci. 53:303-307.

15. Holb, I. J. 2003. Analyses of temporal dynamics of brown rot development on fruit in organic apple production. Int. J. Hortic. Sci. 9:97-100.

16. Holb, I. J. 2004. Yield loss and disease development of Monilinia fructigena (Aderh. \& Ruhl.) Honey in organic apple orchard. J. Agric. Sci. 15:6-8.

17. Holb, I. J., de Jong, P. F., and Heijne, B. 2003. Efficacy and phytotoxicity of lime sulphur in organic apple production. Ann. Appl. Biol. 142:225233.

18. Holb, I. J., Heijne, B., Withagen, J. C. M., Gáll, J. M., and Jeger, M. J. 2005. Analysis of summer epidemic progress of apple scab at different apple production systems in the Netherlands and Hungary. Phytopathology 95:1001-1020.

19. Hong, C. X., Holtz, B. A., Morgan, D. P., and Michailides, T. J. 1997. Significance of thinned fruit as a source of the secondary inoculum of Monilinia fructicola in California nectarine orchards. Plant Dis. 81:519524.

20. IFOAM. 1989. Basic Standards for Organic Agriculture. Tholey-Theley Press, New York.

21. Jenkins, P. T., and Reinganum, C. 1965. The occurrence of a quiescent infection of stone fruits caused by Sclerotinia fructicola (Wint.) Rehm. Aust. J. Agric. Res. 16:131-140.

22. Lack, H. 1989. The spread of apple brown rot (Monilinia fructigena) by insects. Ann. Appl. Biol. 115:221-227.

23. Landgraf, F. A., and Zehr, E. 1982. Inoculum sources for Monilinia fructicola in South Carolina peach orchards. Phytopathology 72:185-190.

24. Madsen, H. F., and Morgan, C. V. G. 1970. Pome fruit pests and their control. Annu. Rev. Entomol. 15:295-320.

25. Moore, M H. 1950. Brown rot of apples: Fungicide trials and studies of the relative importance of different wound-agents. J. Hortic. Sci. 25:225234.

26. Northover, J., and Cerkauskas, R. F. 1994. Detection and significance of symptomless latent infection of Monilinia fructicola in plums. Can. J. Plant Pathol. 16:30-36.

27. Pinheiro, J., Bates, D., DebRoy, S., and Sarkar, D. 2004. nlme: Linear and Nonlinear Mixed Effects Models. R Package Version 3. R Foundation for Statistical Computing, Vienna.

28. Tate, K. G., and Corbin, J. B. 1978. Quiescent fruit infections of peach, apricot, and plum in New Zealand caused by the brown rot fungus Sclerotinia fructicola. N. Z. J. Agric. 6:319-325.

29. Van Leeuwen, G. C. M., Holb, I. J., and Jeger, M. J. 2002. Factors affecting mummification and sporulation of pome fruit infected by Monilinia fructigena in Dutch orchards. Plant Pathol. 53:787-793.

30. Van Leeuwen, G. C. M., Stein, A., Holb, I. J., and Jeger, M. J. 2000. Yield loss caused by Monilinia fructigena (Aderh. \& Ruhl.) Honey and spatiotemporal dynamics of disease development. Eur. J. Plant Pathol. 106:519528.

31. Weibel, F., and Häseli, A. 2003. Organic apple production-with emphasis on European experiences. Pages 551-583 in: Apples: Botany, Production and Uses. D. C. Ferree and I. J. Warrington, eds. CAB International, Wallingford, UK.

32. William, R. D. 1981. Complementary interactions between weeds, weed control practices and pests in horticultural cropping systems. HortScience 16:508-513.

33. Xu, X. M., Guerin, L., and Robinson, J. D. 2001. Effects of temperature and relative humidity on conidial germination and viability, colonization and sporulation of Monilinia fructigena. Plant Pathol. 50:561-568.

34. Xu. X. M., and Robinson, J. D. 2000. Epidemiology of brown rot (Monilinia fructigena) on apple: Infection of fruits by conidia. Plant Pathol. 49:201-206.

35. Xu, X. M., Robinson, J. D., Berrie, A. M., and Harris, D. C. 2001. Spatiotemporal dynamics of brown rot (Monilinia fructigena) on apple and pear. Plant Pathol. 50:569-578. 